\title{
Comparison of Corporate Culture in Croatia and Germany
}

\author{
Marko Sharich*, Bojan Rosi \\ Faculty of Logistics, University of Maribor, Slovenia, Europa \\ Email address: \\ Marko1saric@net.hr (M. Sharich)
}

\section{To cite this article:}

Marko Sarich, Bojan Rosi. Comparison of Corporate Culture in Croatia and Germany. Journal of Business and Economic Development. Vol. 4, No. 4, 2019, pp. 149-154. doi: 10.11648/j.jbed.20190404.14

Received: October 10, 2019; Accepted: November 12, 2019; Published: December 13, 2019

\begin{abstract}
The topic of the paper is a law that has found its place and application in Germany, and in Croatia it comes in a different form: the Law on the Co-decision of Workers. The co-decision law directly influences German corporate culture. The paper will outline the Act itself, its division, its structure, some general facts about how, when and where it was published, when it came into force, then we will enter into the history of co-decision. Also, a link to the Croatian Labor Code and a part equivalent to German law will be shown. At the end of the paper, a survey on the quality of corporate governance in the Republic of Croatia is presented. The principles of corporate governance of the OECD are important for the successful development of corporate culture. We used scientific methods to produce the work: The historical method involves the process by which various documents can be used to find out what has happened in the past and the course and causes of a particular event, the inductive-deductive method is used in explaining established or discovering new insights and laws, proving the set points, testing hypotheses and predicting future events, and the comparative method involves the process of comparing facts and phenomena with a tendency to identify differences and similarities.
\end{abstract}

Keywords: Corporate Culture, Co-decision, Union, Worker, Croatia, Germany, OECD

\section{Introduction}

The German economy is strongest in the E. U. Its gross domestic product, at $€ 2.5$ trillion, is about 25 percent higher than in France or the UK. In the EU's total GDP of $€ 12.3$ trillion, the Federal Republic of Germany accounts for $20 \%$. The four strategic elements make the German economy very characteristic [1]:

1. The German economy is based on production; German products are such that customers around the world want to buy them; they buy them for quality, reliability and technological innovation, not just for price.

2. Germany is particularly successful in exporting, including exports to the countries whose bridge is growing (China, India, Russia, Brazil).

3. Germany's public finances are well regulated, trade surpluses very high and deficit and debt levels low.

4. Germany's economic success is accompanied by a high level of social solidarity and security. In this respect, it is also important to look at the German (continental) model of corporate governance, which, unlike the Anglo-Saxon, gives a great influence of employees on business in a company. The core institutions of employees of German corporations are codetermination, strong unions and job stability. The legal framework for codetermination prescribes the necessary representation of employees on the Supervisory Board [2].

The German economic model is also called the "socialmarket economy", and among German intellectuals, so-called "ordoliberalism" is very commonly used. The main principles of the German "social market economy" are these [1]:

1. Economic activity is led by so-called social partners, people who own businesses and those who work in them (co-decision), the government does not interfere in their decisions.

2. Independent Authority - The Federal Cartel Office ensures that economic activity takes place under optimal conditions of competition.

3. The Independent Central Bank, now the European Central Bank - maintains low inflation and monetary stability.

4. The federal government controls national revenues and expenditures to ensure they are balanced, as well as maintaining education, training and research systems that provide enterprises with the workforce, skills and scientific innovation. 
The Federal Cartel Office and the Central Bank are not the only ones ensuring fair competition. One of the most important German institutions is the Federal Constitutional Court. All three institutions are not subject to the political influence of parliament and government. Neither of these institutions is headquartered in Berlin. The Federal Cartel Office is headquartered in Bonn, the Central Bank is in Frankfurt, and the Constitutional Court is in Karlsruhe. There is a very broad political consensus for the dispersion of national institutions in the FRY. Regarding the position of the Republic of Croatia, it is significant that the depth of the recession and its duration have shown that the Croatian economy is very vulnerable to external shocks and that it cannot adapt quickly to them. The crisis emphasized the existence of a number of structural weaknesses in Croatia [3]:

1. Restrictions on the conduct of economic policy resulting from high external debt and the structural character of the fiscal deficit,

2. Dependence of part of the economy on vertical state aid primarily to Croatian Railways (public sector), shipyards, agriculture, etc.,

3. Strong dependence of economic operators on government procurement and projects,

4. Poor competitiveness of Croatian products and services in the foreign market, which results from their low technological level,

5. Mismanagement of state property, especially stateowned companies,

6. Extremely low population activity rate, or low labor force employment rate between 15 and 64 years of age of $57.1 \%$,

7. Unfavorable investment climate, especially for larger investments. Workers in the Croatian public sector are well protected as opposed to the real sector where there are different practices. The Croatian public sector, unlike the German one, dictates the price of labor in the market. Namely, non-competitive determination of wages in the still large public sector affect Private sector wages. Croatian problems are also related to high payroll taxes and a mismatch of acquired knowledge and skills with the needs of the Croatian economy.

8. A problem is the non-investment credit rating of the Republic of Croatia, which ranges from BBB- to Ba2, depending on the rating of the rating agencies [4].

9. Insufficient utilization of geo-economic goods in Croatia (water, rail and sea transport, energy, tourism) $5]$.

10. Insolvency of numerous companies in Croatia [6].

11. Excessive business diversification of companies [7].

\section{History of Co-decision: Co-decision from 1848 to 1916}

Professor of Sociology at the Department of Co-decision,
Prof. Walter Müller-Jentsch described the history of codecision in Germany through several stages. According to his journal article (Mitbestimmung, 12/2007), the stages by which co-decision has found a place in the German Constitution will be outlined. He cites the name of Wolfgang Franz, an economist, who advocated co-decision based on the negotiations of capital and workers, not law. Mathematical predictions and history teach us that entrepreneurs want to take and use their power of dissemination and decision making whole, not to share it. Co-decision is a new creation and is not something that, like a collective agreement, the right to strike came originally. Sociologist Otto Neuloh presented the basic principles of co-decision in his book on the organization of enterprises (1956). He talks about three guidelines: 1) Guidelines on the offer of undertakings. 2) Encouraging labor movements. 3) Legislative line.

He believes that co-decision developed precisely from these three guidelines, although he states that it has its roots in 19th-century Christian and social turmoil. When, after 1850, industrial production found its way to Germany, the problem of their right opened up because of the increased number of workers. Who represents them, should they have a say in their decision-making? Such issues are difficult for workers' movements and entrepreneurs to address on their own. In larger companies, the so-called Unterstützungskasse - Workers Support Committee. Such committees, under the leadership of management, would discuss issues between workers, and less often the relationship between workers and management. State intervention was sought by numerous protests by workers in Germany. After a major strike by miners at the turn of the century, the state realized that a conciliatory policy should be enacted between the various stocks, in this case of workers and management. The first co-decision initiative refers to the convening of the German parliament in Frankfurt when drafting legislation to maintain order in businesses. Although there was a lack of workers and the working class in that draft, the public was first introduced to the issue and problem of work and to regulating relationships. The lowest level of administration under that law had to be composed of workers who would elect one board member and one board member, and they would settle disputes, factory orders, etc. This lower level would be extended to boards of workers at the regional level, etc. It was all just a letter on paper and did not come to life. Disagreements occurred in almost all industrial enterprises, and government intervention was necessary to address capital and labor problems. After the miners 'strike, involving about 90,000 people and even military intervention, it was clear that administrative and legal measures were needed to regulate workers' rights. Thus, in 1905, the existence of a works council was legally regulated in Prussia, which at least somewhat calmed this mining story. to which social democracy owes its existence. [8,9]. 


\section{The Law on Participation of Workers in Germany}

\subsection{Tabular Overview of Basic Information About the Law [8]}

Table 1. Law on Participation.

\begin{tabular}{ll}
\hline & LAW ON PARTICIPATION OF WORKERS (GESETZ \\
TITLE & ÜBER DIE MITBESTIMMUNG DER \\
& ARBEITNEHMER) \\
SHORT & LAW CO-OPERATION \\
TYPE & FEDERAL LAW \\
VALID AREA & GERMANY \\
WHERE TO & PUBLISHED MAY 4, 1976.801-8 \\
FIND & \\
ENTRY INTO & JULY 1,1976 \\
FORCE & \\
\hline
\end{tabular}

\subsection{About the Law}

The Law on Employee Co-decision regulates in the Federal Republic of Germany the admission of workers' representatives to the board of directors of companies. The companies covered by the law are legally constituted as joint stock companies, limited partnerships with shares, limited liability companies and companies with more than 2000 employees, in which the committees are equal members, which means that workers and equity owners make up half of the board. Shareholders can make all decisions on the board separately: if there is a conflict between shareholders and workers, the president has the right to vote twice. The president of the council is elected by a two-thirds majority vote and is elected by a majority of shareholders. If this is not the case in the first election cycle, the president is elected by the shareholders themselves, and the workers 'representatives by the workers' representatives. The workers 'share consists of the workers themselves, the workers' representatives, the leading employee and the statutory number of trade union representatives.

\subsection{Structure of the Co-decision Act}

The law consists of five chapters, 41 paragraphs. The first chapter deals with the scope of this law. It is about the type of societies in which the law operates, which has been discussed before. The second chapter deals with the organization of the council, the election of representatives. The number of trade union representatives and workers is precisely defined: For example, in a company with up to 10,000 employees, the board has 6 shareholders and workers each (12 in total), of which 4 are workers and 2 are union representatives, in a company of 10 to 20 thousand employees, the board consists of 8 shareholders and workers (16 in total), of which six are workers and two are union representatives, and in companies over 20 thousand workers, the board has 10 members (20 in total), 7 of which are workers and three union representatives. The creation of the council shall take into account gender equality, professional qualifications, etc. The members of the works council shall be elected through a delegate, who shall be elected by secret ballot. Earlier in the paper, the possibility of a two-vote was mentioned, and it is given to the chairman of the panel if the panel fails to vote twice because of an equal number of votes. The President's vote is then counted as a double vote. Chapter 3 defines the internal order, rights and tasks of the council. Workers participating in the committee are protected in such a way that they do not decline in business development, that is, they are not interfered with in the performance of their duties in the company in any way, even though they are members of the council. Chapter four writes about maritime transport and how the council operates. The lead in this case is the representative - the captain of the ship. The ships described in this section of the law refer to merchant ships flying the flag of the FRY. Chapter Five describes the transitional and final provisions of this law and its entry into force $[8,9]$.

\section{Croatian Law - The Workers' Council}

The fundamental powers of the workers' council in the Labor Law are defined in Article 148 and read as follows:

1. The Workers' Council shall protect and promote the interests of workers employed by a particular employer, by consulting, co-deciding or negotiating with the employer or a person authorized by him, on matters relevant to the position of the worker.

2. The Workers' Council shall observe the observance of this Law, the Rules of Procedure, collective agreements and other regulations.

3. The Workers' Council shall ensure that the employer duly and accurately fulfills the obligations of calculating and paying contributions in accordance with a special regulation, and for this purpose is entitled to inspect the relevant documentation.

4. The Workers' Council shall not participate in the preparation or implementation of a strike, dismissal or other industrial action, nor interfere in any way with the collective labor dispute which may give rise to such action.

Workers employed by an employer who employs at least twenty workers, with the exception of workers employed in state administration bodies, have the right to participate in the decision-making on issues related to their economic and social rights and interests in the manner and under the conditions prescribed by this Act. Article 141 refers to the right to elect a works council:

1. Workers shall have the right, by free and direct election, by secret ballot, to elect one or more of their representatives (hereinafter: the works council) to represent them with the employer in the protection and promotion of their rights and interests.

The number of members of the works council is determined by Article 142:

1) The number of members of the works council shall be determined by the number of workers employed by a particular employer, namely:

1) Up to seventy-five workers, one representative. 
2) From seventy-six to two hundred and fifty workers, three representatives.

3) From two hundred and fifty-one to five hundred workers, five representatives.

4) From five hundred to seven hundred and fifty workers, seven representatives.

5) From seven hundred and fifty-one to one thousand workers, nine representatives.

2) The number of members of the works council shall be increased by two for every one thousand new workers started.

3) When proposing the members of the works council, it is necessary to take into account the equal representation of all organizational units and groups of employed workers (by gender, age, qualification, jobs in which they work and the like).

The employer may only, with the prior consent of the works council, decide:

1) Dismissal of a member of the works council.

2) Dismissal of a candidate for a member of the Workers' Council who has not been elected, within a period of three months after the final election results have been determined.

3) Dismissal of an employee whose work injury or occupational disease resulted in a decrease in working ability with the remaining working capacity or a decrease in working capacity with a partial loss of working capacity, or a termination of the worker to a disabled person.

4) Dismissal to a worker over sixty years of age.

5) Dismissal of the employee representative in the employer body.

6) The listing of persons referred to in Article 34, paragraph 1 of this Law in the collective redundancy of employees, except in cases where the employer initiated or carries out liquidation proceedings in accordance with a special regulation.

7) Collecting, processing, using and submitting to third parties information about the worker.

8) The appointment of a person authorized to supervise whether the personal data of workers are collected, processed, used and disclosed to third parties in accordance with the provisions of this Act.

2. The employer may exceptionally, without the prior consent of the workers' council, make the decision referred to in paragraph 1, items 1 to 6 of this Article, if the decision decides on the rights of workers, who is also a union commissioner enjoying the protection referred to in Article 188 of this Act [10-12].

\section{Comparison of Croatian and German Law}

This chapter will compare the laws governing the codecision of workers with respect to several points.

1. Establishment of a council: In the Republic of Croatia, the Labor Law states in an article that workers may establish a council (Article 141), but it's not their obligation. In this way, they have already been degraded in relation to Germany, where it is prescribed when and how the council is established.

2. Council composition: In the German legal system, the participation of workers has been resolved by a separate law on employee co-decision, while the Croatian law has addressed the issue of co-decision within labor law, in one of the articles.

3. Extent: Germany has resolved the issue of co-decision with a separate Act on co-decision and thus more comprehensively described the occurrence of employee co-decision compared to Croatia.

4. Scope: In the Croatian Labor Code, the issue of codecision is stated precisely within its scope, ie when workers have the right to participate in decisionmaking. German law was based on council structure and rights and tasks.

5. Council structure: It is described in both countries but is different. For example, in Croatia the number of workers and their representatives is precisely defined, while in Germany there are higher numbers. The Governing Council is larger in Germany because there are more workers. In Germany, it is precisely defined by what number it consists, while in Croatian law they describe to what number of workers comes how many MPs. Labor representation in Croatia is fading and small companies are being established, with fewer workers and therefore fewer rights.

6. Equality: The Workers' Council in both Laws takes care of equality mentioned above. Legal implementation: Thorough implementation of each law is one of the qualities of Germany as a state. There are different practices in the private and public sector in Croatia.

7. Employment Opportunity: In Germany, the labor market is huge, enticing and diverse, as best illustrated by the number of Croatian nationals who go there in search of a better life. In relation to this demand, workers may be "louder" in claiming their rights. Should the employer express a negative attitude, the worker changes his job because of a well-developed market economy.

8. Historical turmoil: Germany, as a state, is governed by laws that are long overdue, changing neither the new government nor the new regime. They remain steady. It is a country with a long history, unlike the Republic of Croatia, which is a relatively young country, and has taken a lot from its legal state ancestor - the former Yugoslavia, as a socialist state that regulated the rights of workers in a completely different way.

\section{Research on the Quality of Corporate Governance in the Republic of Croatia}

Croatia is a classic example of a country that has had 
problems implementing two sets of corporate governance laws, adapted from two different legal backgrounds. Corporate law is based on the German model (often driven by creditors often banks), while securities law is strongly tied to the Anglo-American system focused on the market (driven by investors). In this indicative study we will examine the quality of corporate governance. In view of the fact that it is Croatia's political and economic ambition to be a member of the prestigious OECD Club in this regard, we place emphasis on this research.

Table 2. Implementation of OECD Corporate Governance Principles in the Republic of Croatia.

\begin{tabular}{ll}
\hline IMPLEMENTATION OF & PERCENTAGE OF \\
OECD & RESPONDENTS \\
\hline HIGH & $10 \%$ \\
MEDIUM & $40 \%$ \\
LOW & $60 \%$ \\
\hline
\end{tabular}

Source: Companies surveyed and number of employees per company approx.: All market media d. o. o. 18, Antenna FM d. o. o. 5, Enter Zagreb d. o. o. 9 Media service global d. o. o. 10 media TOWER d. o. o. 15, Family Radio d. o. o. 7, Radio Croatia d. o. o. 6, Gold FM d. o. o. 7, ULTRA FM d. o. o. for Media Services 12, UMA FM d. o. o. 4 Top Radio Production d. o. o. 1 TOTAL: 94.

Corporate governance standards in Croatia are relatively low. Applying accounting standards, the role of supervisory boards has not been developed to attract greater investor interest. The introduction of the highest corporate governance standards should not be limited to listed companies. Applying OECD corporate governance principles to state-owned enterprises is an ideal instrument for preparing privatization and / or improving the quality of governance in those nonprivately owned public companies. The OECD principles also help to professionalize management and increase the overall efficiency of enterprises. The above indicative survey conducted on 94 employees of 11 companies shows that the perception of the implementation of OECD principles of corporate governance is at the mid-level in the Republic of Croatia. One of the key foreign policy goals is membership of the Organization for Economic Co-operation and Development (OECD, Fr. Organization for Co-operation and Economic Development or OECD). The indirect positive effects of OECD membership can be discussed in terms of the country's credit rating and the overall image of the country and its economy and the development of corporate culture. It shows that Croatia's withdrawal from the OECD would only hurt, and in no way assist in trying, attracting investment from abroad or establishing a good negotiating position in foreign trade arrangements with non-EU countries [13-15].

\section{Conclusion}

Germany has brought its labor-legal structure to an enviable level. The culture possessed by its citizens and patterns of behavior, even towards foreigners, speak a lot about that country. Long-term political stability, membership in all relevant international institutions (WTO, EU, Schengen security regime, euro zone, $\mathrm{OECD}$, high credit rating) gives a very optimistic perspective of the Federal Republic of Germany. Nor is the Republic of Croatia without chances in a globalized economic environment. For only 27 years, the Republic of Croatia is an internationally recognized fact, it faces an unfinished transition, but also full membership of the EU and NATO. Croatia's fear of capitalism, even of the so-called German so-called liberalism, is completely unjustified. We must not forget that Germany is a state of high economic freedoms, where workers are well protected, but also entrepreneurial freedom very large in 2016 as well. it ranked 17th on the World Economic Freedom Table, unlike Croatia's 103th or Greece's 138th. Employees in developed market economies and regulated liberal Democracies, they are consuming high standards of living and relatively good wages, primarily because of the huge accumulation of capital and competition among employers and large capitalists. This is especially important for Croatia, which is in a phase of unfinished transition and should not restrict economic freedoms, since they are not contrary to labor rights [13-15].

\section{References}

[1] Lever P.; Kako Berlin vlada Europom, Profil 2018.

[2] Tipurić D. Korporativno upravljanje, Sinergija, 2008.

[3] Šarić, M. (2013). VAŽNOST RESTRUKTURIRANJA HRVATSKOG JAVNOG SEKTORA. Tranzicija, 15 (32), 131143. Preuzeto s https://hrcak.srce.hr/112868 19.9.2018.

[4] Šarić M., Šprem B. Elementi za formiranje kreditnog rejtinga, poglavlje u knjizi: „Instrumenti kontrolinga“, poslovna učinkovitost, Zagreb, 2017.

[5] Šarić, Marko. 2018. "Croatia and Hungary, a Geo-Economical Position Within the European Union". Account and Financial Management Journal 3 (04), 1472-79.

[6] Šarić M. Važnost predstečajnog postupka, poslovna učinkovitost, Zagreb 2019.

[7] Šarić M. 24. Diverzifikacija u funkciji poslovne izvrsnosti, poglavlje u knjizi: "MENADŽMENT I KONTROLING", poslovna učinkovitost, Zagreb, 2018.

[8] Zakon o suodlučivanju radnika, preuzet $\mathrm{s}$ poveznice: http://www.gesetze-im-internet.de/mitbestg/index.html posjećena stranica (2.9.2016.).

[9] Časopis Mitbestimmung, 12/2007 dostupan na poveznici: http://www.boeckler.de/34820.htm (31.8.2016.).

[10] Zakon o radu, preuzet $\mathrm{s}$ poveznice: http://www.zakon.hr/z/307/Zakon-o-radu (2.9.2016.).

[11] Glas Koncila 36, od 5.9.2004. preuzeto sa stranice: $\mathrm{http}: / /$ www.glas-

koncila.hr/index.php?option $=$ com_php\&Itemid $=41 \&$ news_ID $=1695$, (31.8.2016.).

[12] Deklaracija o pravima čovjeka, preuzeta $\mathrm{s}$ poveznice: https://hr.wikipedia.org/wiki/Op\%C4\%87a_deklaracija_o_pra vima_\%C4\%8Dovjeka zadnji put posjećena (31.8.2016). 
[13] https://www.scribd.com/doc/297413656/Indeks-ekonomskihsloboda-2016-Grafovi 19.8.2017.

[14] Šarić M. Restrukturiranje i organizacija velikih javnih poduzeća: specijalistički poslijediplomski rad, Ekonomski fakultet Zagreb (2012).
[15] Vlada RH: Strateški okvir za razvoj 2006-2013, Središnji državni ured za strategiji, ZAGREB, 2006. 